\title{
COMBINING ABILITY AND HETEROSIS ESTIMATES FROM LINE $X$ TESTER MATING DESIGN UNDER WATER STRESS CONDITIONS IN RICE (Oryza sativa L.)
}

Hassan, H. M. ; S. A. A. Hammoud ; A. M. El-Moghazy and A. B. El-Abd

Rice Research Section, Filed Crops Research Institute, ARC, Giza, Egypt.

\begin{abstract}
A Study on combining ability and heterosis were conducted on $15 \mathrm{~F} 1$ hybrids along with eight rice genotypes (five lines and three testers) to understand the pattern of inheritance of yield, its components and some root traits for selecting superior genotypes. The experiment was carried out using line $x$ tester mating design, during 2010-2011 rice growing seasons at the experimental farm of Rice Research and Training Center, Sakha, Kafr El-Sheikh, Egypt. Analysis of variance revealed significant differences among genotypes, lines, testers and line $\mathrm{x}$ tester interactions for days to $50 \%$ heading, plant height, panicle length and weight, number of filled grains/panicle, number of panicles/plant, number of roots/plant, root length and volume and grain yield/plant traits under water stress conditions, indicated that the genotypes had wide genetic diversity for the studied traits. Significance of the means of sum squares due to lines and testers indicated a prevalence of additive variance. However, significant differences due to interactions of line $x$ tester for the above mentioned traits, indicating the importance of both additive and non-additive variance in the inheritance of these traits. The mean squares due to GCA as well as SCA were significant for all studied traits except 100- grain weight and root/shoot ratio. Thus, the significance of GCA (variances due to lines and testers) and SCA (variances due to lines $\mathrm{x}$ testers) implied that both additive and non-additive types of variation was available for all the traits, yet additive genes were more important than the dominant genes because variance due to GCA was higher than that of SCA for all mentioned traits. Moreover, the ratio of GCA and SCA variances was greater than unity for all the traits studied that revealed the preponderance of additive gene action over the nonadditive gene action. IET 1444, Morobrekan and Giza 178 rice genotypes were the best general combiners due to highly significant GCA effects for number of roots/plant, root volume and root length traits. Moreover, Wab 450-JR-4-1-1 as tolerant to water stress conditions was the best general combiner for panicle weight, number of filled grains/panicle, otherwise, Sakha 102, rice genotype was the poorest combiner comparing with other rice genotypes for all the studied traits, except days to $50 \%$ heading. The crosses, Sakha $105 \times$ IET 1444, Sakha $103 \times$ Sakha 102 and Morobrekan $x$ Wab 450-JR-4-1-1 were found to be the best cross combinations for most of the studied traits; these crosses had high and significant SCA in desirable direction under water stress conditions.

Highly significant and positive estimates of heterosis and heterobeltiosis were recorded in Morobrekan x IET 1444, Sakha 105 x IET 1444 and Sakha 104 x Sakha 102 for number of panicles/plant, panicle length and number of roots and their volume/plant, respectively. The highest estimated values of phenotypic ( $\mathrm{pph}$ ) and genotypic $(\mathrm{Vg})$ variances were observed for number of filled grains/panicle, root number/plant and root volume indicating better scope for the genetic improvement in these three mentioned traits. High broad-sense heritability, coupled with high genetic advance, were observed for plant height, panicle weight, number of panicles/plant, sterility $\%$ and grain yield/plant, indicating the role of additive genetic variance in the
\end{abstract}


Hassan, H. M. et al.

expression of these traits and direct selection might be highly effective in early generations to improve these traits under water stress conditions.

Keywords: rice, combining ability, water stress conditions, heterosis, yield, root traits and line $x$ tester design

\section{INTRODUCTION}

Rice (Oryza sativa L.) is the most important food crop of the world; but drought stress is a serious constraint for factor to rice production and yield stability in rainfed areas. Breeding for drought tolerance is a challenging task because of the complexicity of the component traits, screening technique, environmental factors and their interactions. The major setback in drought tolerance breeding is the poor understanding of genetics and inheritance of drought tolerance traits and complete ignorance about the physiological drought tolerance attributes as well as the mechanisms related drought. Alternatively, yield and roots improvements in water-limited environments can be achieved by selecting for secondary traits contributing to drought tolerant in breeding programs.

The success of a plant breeding program greatly depends on right choice of parents for hybridization and the gene action of different economic traits. Combining ability analysis provides such information so as to frame the breeding program effectively. The line $\mathrm{x}$ tester analysis gives reliable information about the nature and magnitude of gene action and combining ability effects present in the genetic materials. Dhillon, (1975) pointed out the combining ability gives useful information on the choice of parents in terms of expected performance of the hybrids and their progenies. The line $x$ tester analysis method is used to breed both self and cross-pollinated plants and to estimate favorable parents and crosses, and their general and specific combining abilities (Kempthorne, 1957). Combining ability analysis is an important tool for the selection of desirable parents together with the information regarding nature and magnitude of gene effects controlling quantitative traits (Basbag et al., 2007). GCA and SCA which identify the hybrids with high yield are the most important criteria in breeding programs (Ceyhan, 2003).

The performance of parent may not necessarily reveal it to be a good or poor combiner. Therefore, gathering information on nature of gene effects and their expression in terms of combining ability is necessary. At the same time, it also elucidates the nature of gene action involved in the inheritance of characters. General combining ability (GCA) is attributed to additive gene effects and additive $x$ additive epistasis and is theoretically fixable. On the other hand, specific combining ability attributable to non-additive gene action may be due to dominance or epistasis or both and is non-fixable. The presence of non-additive genetic variance is the primary justification for initiating the hybrid program ( Pradhan et al., 2006).

Accordingly, the present investigation was undertaken to get an idea of the combining ability for yield and some root traits with a view to identify good combiners which may be used to create a population with favorable genes for yield and root traits in rice, and it was also carried out to study the 
heterosis manifested by the hybrids over mid parent and better parents, heritability and genetic parameters for the studied traits in relation to drought tolerance in rice.

\section{MATERIAL AND METHODS}

The experiment was carried out using line $x$ tester mating design, during 2010-2011 rice growing seasons at the experimental farm of Rice Research and Training Center (RRTC), Sakha, Kafr El-Sheikh, Egypt. The experimental material of the present study comprised five lines namely; Giza 178 and Morobrekan (tolerant genotypes for drought), Sakha 104 (moderately tolerant); and Sakha 103 and Sakha 105 (sensitive genotypes to drought); and three testers namely; IET 1444 and and Wab 450-JR-4-11 (tolerant genotypes for drought) and Sakha 102 (sensitive genotype to drought) with diverse pure and elite genotypes of rice. The parents were selected on the basis of different genetic and geographical origin. The testers used for this study was of subcontinent origin and were well adapted to Egyptian locality and their yield potential was up to the mark (The lines were originated from RRTC, Egypt).

In 2010, the five lines and three testers were grown at RRTC farm in three successive dates of planting with ten intervals in order to overcome the differences in flowering time between parents. Thirty days old seedlings of each parent were individually transplanted in the permanent field in seven rows. Each row was $5 \mathrm{~m}$ long and contained 25 hills. At flowering time, hybridization between the parents was carried out following the technique proposed by Jodon (1938) to produce their F1 using line $x$ tester meating design.

The resulted fifteen hybrids and their parents were grown in randomized complete block design with three replications. The hybrids and their parents were transplanted with a spacing of $20 \mathrm{~cm}$ between rows and 20 $\mathrm{cm}$ between plants and flush irrigation was used every 8 days for the drought conditions, during 2011 summer season. Recommended cultural practices were followed for the two conditions. The following observation were made on randomly selected fifteen plants from each row of each replication for the studied traits viz., Days to $50 \%$ heading, plant height $(\mathrm{cm})$, panicle length $(\mathrm{cm})$, panicle weight $(\mathrm{g})$, number of filled grains/ panicle, sterility \%, number of panicles/plant, 100 grain weight $(\mathrm{g})$, grain yield/plant $(\mathrm{g})$. For root measurements, 20 rice plants from each genotype were grown in plastic bag, one plant per bag. The bag was $20 \mathrm{~cm}$ in diameter and $0.5 \mathrm{~m}$ in length with holes on the top and down two sides. Bags were placed with water deficit treated basin. The studied root traits, root length, root volume, number of roots/plant and root/soot ratio were scored at the maximum tillering stage. To measure these traits, the plastic bag containing the soil and roots was pulled out from the basins. The lowest visible root in the soil after removing the plastic bag was scored as the maximum root length (in centimeters). The body of soil and roots was cut from the basal node of the plant and the soil 
was washed away carefully to collect roots, then the above mentioned root traits were measured.

Analysis of variance was computed for each season assuming that the cultivars under study are random. As the error variances of the experiments were statistically homogeneous, the two experiments were statistically combined over the two seasons, according to Le Clerg et al. (1962), then, it was subjected to analysis of variance, which was used to partition the gross phenotypic variability into the components due to genetic (hereditary) and non-genetic (environmental) factors and to estimate the magnitude of them. Genotypic variance is the part of the phenotypic variance, which can be attributed to genotypic differences among the phenotypes. Similarly, phenotypic variance is the total variance among phenotypes, when grown over the range of environments of interest, Dudley and Moll (1969). Hence, variance components, genotypic $(\mathrm{Vg})$, phenotypic $(\mathrm{Vp})$ and error $(\mathrm{Ve})$ variances were estimated using the formula of Wricke and Weber (1986) and Prasad et al. (1981), as follows:

$$
\begin{aligned}
\mathrm{Vg} & =[\mathrm{MSG}-\mathrm{MSE} / \mathrm{r}] \\
\mathrm{Vph} & =[\mathrm{MSG} / \mathrm{r}] \\
\mathrm{Ve} & =[\mathrm{MSE} / \mathrm{r}]
\end{aligned}
$$

Where, MSG, MSE and $r$ are the mean squares of genotypes, mean squares of error and number of replications, respectively.

Where, $\mathrm{Vp}, \mathrm{Vg}$ and $\mathrm{X}$ are the phenotypic variances, genotypic variances and grand mean per season, respectively, for the traits under consideration. Broad-sense heritability (h2B), expressed as the percentage of the ratio of the genotypic variance $(\mathrm{Vg})$ to the phenotypic variance $(\mathrm{Vph})$ was estimated on genotypic mean basis, as described by Allard (1999). Genetic advance (GA) expected and GA as percent of the mean, assuming selection of the superior $5 \%$ of the genotypes were estimated in accordance with the methods, illustrated by Fehr (1987), as follows:

$$
\mathrm{GA}=\mathrm{K}(\mathrm{S} \text { ph) h2 B }
$$

$\mathrm{GA}($ as $\%$ of the mean $)=(\mathrm{GA} / \mathrm{x}) \times 100$

Where, $\mathrm{k}$ is a constant (which varies depending upon the selection intensity and, if the latter is $5 \%$, it stands at 2.06). (S ph) is the phenotypic standard deviation $(\sqrt{ } \mathrm{Vph}), \mathrm{h} 2 \mathrm{~B}$ is the heritability ratio and $\mathrm{x}$ refers to the season mean of the trait. The phenotypic correlation coefficients were computed, according to the method of Dewey and Lu (1959).

Combining ability analysis was done using line $x$ tester method (Kempthorne, 1957). The variances for general combining ability and specific combining ability were tested against their respective error variances derived from ANOVA reduced to mean level. Significance test for GCA and SCA effects were performed using t-test.

The heterosis were estimated as the deviation of the $F_{1}$ mean value from the mid- and better-parent mean values as suggested by Matzinger et al. (1962) and Fonsecca and Patterson (1968), respectively. The following formulae were used for the estimation of mid-parent (MP) and better-parent (BP) heterosis for all the traits:

Heterosis over the mid-parent $=\left[\left(F_{1}-M P\right) / M P \times 100\right]$, S.E. $\left(F_{1}-M P\right)=(3 M e / 2 r)^{1 / 2}$, 
Heterosis over the better-parent $=\left[\left(F_{1}-B P\right) / B P \times 100\right]$, and S.E. $\left(F_{1}-B P\right)=(2 \mathrm{Me} / \mathrm{r})^{1 / 2}$.

Where, $\mathrm{Me}=$ error mean squares for parents and $F_{1} s$ from an individual environment; $M P=$ mean mid-parent value $=\left(P_{1}+P_{2}\right) / 2 ; P_{1}=$ mean performance of parent one; $\mathrm{P}_{2}=$ mean performance of parent two; $\mathrm{BP}$ $=$ mean of better-parent value; $\mathrm{R}=$ number of replications.

\section{RESULTS AND DISCUSSION}

\section{Analysis of variance}

The recorded data on different yield and root characteristics were subjected to analysis of variance to confirm the differences among rice genotypes. Mean squares from analysis of variance of all studied traits of rice are presented in Table (1). The table depicted highly significant differences among rice genotypes for all the studied traits. Sum of squares of rice genotypes for traits were further portioned into parents, crosses and parents vs. crosses, which revealed highly significant differences among genotypes. The significant component of variance due to parents vs. crosses indicated prevalence of heterosis for all studied traits. The sum of squares calculated for rice crosses were further portioned into lines, testers and line $x$ tester components. Highly significant $(P \leq 0.01)$ differences were displayed among line $x$ tester interaction for most of the studied traits. However, non-significant differences existed among lines and testers and line $x$ tester components for 100 -grain weight trait. The mean squares due to GCA as well as SCA were significant for all the studied traits, except 100- grain weight and root/shoot ratio. Thus, the significance of GCA (variances due to lines and testers) and SCA (variances due to lines $x$ testers) implied that both additive and nonadditive types of variation was available for all the traits, yet additive genes were more important than the dominant genes because variance due to GCA was higher than that of SCA for all mentioned traits. Moreover, the ratio of GCA and SCA variances was greater than unity for all the studied traits that revealed the preponderance of additive gene action over the non-additive gene action for all studied traits. The results suggest that improvement in these traits may be obtained via heterosis breeding or by single plant selection in later generations following hybridization or intermating of selected segregants through recurrent selection. plant height were governed by additive gene action; and pure line selection, mass selection, progeny selection and pedigree breeding can be used to improve it, Gomez, et al. (2003). Similar results also were reported previously by Abd Allah, (2004 a and b), Amudha, et al. (2007), Basbag et al. (2007) and Viswanathan and Thiyagarajan, (2008), they exhibited that high magnitude of specific combining ability (SCA) variance revealed the predominance of non-additive gene action for all characters, viz., days to 50 per cent flowering, plant height, number of productive tillers per plant, panicle length, number of filled grains per panicle, spikelet fertility, 100 grain weight and grain yield per plant which offer scope for exploitation of hybrid vigour through heterosis breeding. 
Table (1): Mean squares from line $x$ tester analysis for yield and its related traits under water stress condition during 2011 growing season.

\begin{tabular}{|c|c|c|c|c|c|c|c|c|c|c|}
\hline S.O.V & d.f & 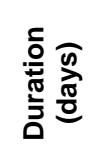 & 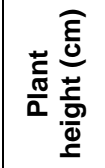 & 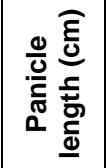 & $\begin{array}{l}\frac{0}{0} \\
\frac{0}{0} \\
\frac{}{\pi} \\
\frac{5}{\pi} \\
\frac{0}{0}\end{array}$ & 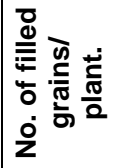 & 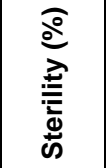 & 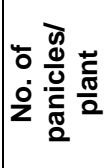 & 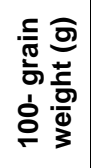 & 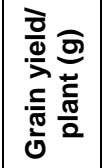 \\
\hline Replications & 2 & 1.57 & 1.21 & 0.14 & 0.15 & 1.15 & 0.20 & 1.07 & 0.006 & 0.56 \\
\hline Genotypes & 22 & $184.90^{\star *}$ & $805.38^{* *}$ & $17.55^{\star \star}$ & $1.24^{* \star}$ & $1001.03^{\star \star}$ & $57.63^{\star \star}$ & $52.35^{\star \star}$ & $0.136^{* \star}$ & $105.13^{\star *}$ \\
\hline Parents & 7 & $159.90^{\star *}$ & $1200.5^{\star *}$ & $22.80^{\star *}$ & $1.24^{\star *}$ & $1927.08^{\star \star}$ & $55.28^{\star \star}$ & $22.51^{\star \star}$ & $0.321^{* *}$ & $153.62^{\star \star}$ \\
\hline \begin{tabular}{|l|} 
Parents \\
Crosses
\end{tabular} & 1 & 520.50 ** & $941.45^{\star *}$ & $122.76^{* *}$ & $4.14^{\star *}$ & $341.27^{* *}$ & $113.44^{* *}$ & $324.39 * *$ & $0.142^{* *}$ & $195.99 * \star$ \\
\hline Crosses & 14 & $173.43^{\star \star}$ & $598.06^{* *}$ & $7.42^{* *}$ & $1.03^{\star *}$ & $585.13^{* *}$ & $54.82^{\star \star}$ & $47.84^{\star \star}$ & $0.044^{\star \star}$ & $74.39^{\star \star}$ \\
\hline Lines & 4 & $277.86^{\star *}$ & $1826.2^{* *}$ & $9.14^{* *}$ & $0.39^{* *}$ & $807.47^{* *}$ & $26.58^{\star \star}$ & $10.12^{\star *}$ & 0.053 & $173.98^{\star *}$ \\
\hline Testers & 2 & $540.46^{\star *}$ & $162.75^{* *}$ & $8.67^{* *}$ & $5.17^{\star *}$ & $555.82^{* *}$ & $251.88^{\star *}$ & $272.32^{* *}$ & 0.033 & $39.68^{* *}$ \\
\hline Lines $\mathbf{x}$ Testers & 8 & $29.46^{\star \star}$ & $92.81^{\star *}$ & $6.24^{* *}$ & $0.31^{* *}$ & $481.29^{\star \star}$ & $19.67^{\star \star}$ & $10.57^{\star *}$ & 0.042 & $33.28^{\star \star}$ \\
\hline Error & 45 & 5.20 & 4.92 & 3.26 & 0.03 & 6.05 & 2.05 & 3.32 & 0.033 & 3.06 \\
\hline GCA / SCA & & 2.25 & 2.30 & 1.08 & 1.52 & 1.04 & 1.42 & 2.08 & 1.044 & 1.28 \\
\hline
\end{tabular}

*and ${ }^{* *}$ significant at 0.05 and 0.01 probability levels, respectively.

Table (1): Continuous

\begin{tabular}{|c|c|c|c|c|c|}
\hline S.O.V & d.f & $\begin{array}{c}\text { Root } \\
\text { numbers }\end{array}$ & $\begin{array}{l}\text { Root volume } \\
(\mathrm{mm})\end{array}$ & $\begin{array}{l}\text { Root length } \\
(\mathrm{cm})\end{array}$ & $\begin{array}{c}\text { Root } / \text { Shoot } \\
\text { ratio }\end{array}$ \\
\hline Replications & 2 & 1.08 & 0.62 & 1.14 & 0.012 \\
\hline Genotypes & 22 & $6202.01^{\star \star}$ & $4610.19^{\star \star}$ & $172.48^{\star \star}$ & $0.127^{\star \star}$ \\
\hline Parents & 7 & $6350.23^{\star \star}$ & $4069.42^{\star \star}$ & $201.97^{\star \star}$ & $0.138^{\star \star}$ \\
\hline Parents vs. Crosses & 1 & $6402.53^{\star \star}$ & $3783.38^{\star \star}$ & $122.22^{\star \star}$ & $0.462^{\star \star}$ \\
\hline Crosses & 14 & $6113.58^{\star \star}$ & $4939.64^{\star \star}$ & $161.32^{\star \star}$ & 0.098 \\
\hline Lines & 4 & $5732.25^{\star \star}$ & 4296.74** & $372.58^{\star \star}$ & $0.158^{\star}$ \\
\hline Testers & 2 & $15048.20^{\star *}$ & $10045.42^{\star \star}$ & $268.02^{\star \star}$ & 0.009 \\
\hline Lines x Testers & 8 & $4070.58^{\star \star}$ & $3984.64^{\star \star}$ & $29.02^{\star \star}$ & 0.090 \\
\hline Error & 45 & 17.38 & 10.14 & 4.92 & 0.008 \\
\hline GCA / SCA & & 1.11 & 1.05 & 2.16 & 1.020 \\
\hline
\end{tabular}

*and ${ }^{* *}$ significant at 0.05 and 0.01 probability levels, respectively

\section{Per se performance of the studied rice genotypes}

Conspicuously, Table (2) shows that the tallest plants which favorite for rice breeders under water stress conditions were observed in Morobrekan followed by Sakha 103 and Sakha 104, while, the shortest ones were exhibited in Sakha 105, IET 1444 and WAB 450-JR-4-1-1 rice varieties. Sakha 105 followed by Sakha 102 and Sakha 103, were the earlier rice cultivars. Otherwise, WAB 450-JR-4-1-1, IET 1444 and Morobrekan were the latest rice cultivars comparing with other rice cultivars. In addition, Morobrekan has a longest panicle $(25.00 \mathrm{~cm})$, and many number of filled grains/panicle (158.00 grains). The superior panicle weight $(4.20 \mathrm{~g})$ was obtained for WAB 450-JR-4-1-1. Many number of panicles/plant were detected for IET 1444 followed by Morobrekan. WAB 450-JR-4-1-1 was found to be the heaviest grains rice cultivar (3.03 g/100 grains). Low sterility \% was observed for Sakha 102, IET 1444 and Giza 178 rice genotypes comparing with the other cultivated parents. The parental mean values of grain yield were ranged between 21.46 and $37.93 \mathrm{~g} /$ plant for Morobrekan and WAB 450- 
JR-4-1-1, respectively. Moreover, Giza 178 was recorded the highest number of roots and root/shoot ratio, while the highest root volume and root length were observed on IET 1444 rice genotype, their estimated values were $125.00 \mathrm{~mm}$ and $37.97 \mathrm{~cm}$, respectively. On the contrary, Sakha 103 was found to has the lowest number of roots, root volume and the shortest root length. According to the presented results, Morobrekan followed by WAB 450-JR-4-1-1 were the best rice genotypes under water stress condition, so, rice breeders should be use it as donors to improving new rice variety in their breeding program.

Table (2): Mean performance of crosses, lines and testers for the studied traits under water stress conditions during 2011 growing season.

\begin{tabular}{|l|c|c|c|c|c|c|}
\hline \multicolumn{1}{|c|}{ Genotype } & $\begin{array}{c}\text { Duration } \\
\text { (days) }\end{array}$ & $\begin{array}{c}\text { Plant } \\
\text { height } \\
\text { (cm) }\end{array}$ & $\begin{array}{c}\text { Panicle } \\
\text { length } \\
\text { (cm) }\end{array}$ & $\begin{array}{c}\text { Panicle } \\
\text { weight (g) }\end{array}$ & $\begin{array}{c}\text { No. of } \\
\text { filled } \\
\text { grains/ } \\
\text { panicle }\end{array}$ & $\begin{array}{c}\text { Sterility } \\
\text { (\%) }\end{array}$ \\
\hline Line 1- Giza 178 & 112.00 & 86.67 & 19.00 & 3.33 & 125.33 & 7.37 \\
\hline Line 2- Sakha 103 & 111.33 & 92.00 & 15.33 & 2.77 & 112.33 & 8.83 \\
\hline Line 3- Sakha 104 & 113.00 & 90.00 & 19.00 & 2.73 & 82.00 & 6.67 \\
\hline Line 4- Sakha 105 & 109.67 & 78.33 & 18.33 & 2.80 & 84.00 & 9.43 \\
\hline Line 5- Morobrekan & 124.67 & 141.67 & 25.00 & 3.70 & 158.00 & 8.43 \\
\hline Tester 1- IET 1444 & 125.00 & 83.33 & 19.00 & 2.20 & 98.33 & 5.40 \\
\hline Tester 2- Sakha 102 & 110.33 & 89.67 & 21.00 & 3.50 & 109.00 & 5.20 \\
\hline Tester 3- WAB450-JR-4-1-1 & 126.00 & 85.00 & 18.33 & 4.20 & 130.00 & 18.67 \\
\hline Giza 178 x IET 1444 & 128.33 & 85.33 & 22.17 & 3.50 & 134.67 & 15.17 \\
\hline Giza 178 x Sakha 102 & 116.00 & 99.33 & 23.07 & 3.27 & 127.67 & 11.10 \\
\hline Giza 178 X WAB 450 & 133.00 & 93.33 & 24.17 & 4.70 & 133.33 & 14.90 \\
\hline Sakha 103 x IET 1444 & 123.33 & 97.00 & 21.17 & 3.07 & 105.33 & 11.83 \\
\hline Sakha 103 x Sakha 102 & 115.00 & 96.33 & 20.27 & 3.97 & 130.00 & 5.03 \\
\hline Sakha 103 x WAB 450 & 129.67 & 105.33 & 20.17 & 4.33 & 116.00 & 17.33 \\
\hline Sakha 104 x IET 1444 & 121.67 & 93.00 & 23.07 & 3.27 & 103.67 & 11.50 \\
\hline Sakha 104 x Sakha 102 & 114.67 & 93.67 & 21.23 & 3.63 & 95.33 & 5.00 \\
\hline Sakha 104 x WAB 450 & 119.67 & 108.67 & 24.20 & 4.53 & 142.00 & 13.83 \\
\hline Sakha 105 x IET 1444 & 113.00 & 89.33 & 25.17 & 3.13 & 104.33 & 5.50 \\
\hline Sakha 105 x Sakha 102 & 112.00 & 85.33 & 21.43 & 3.23 & 103.00 & 6.50 \\
\hline Sakha 105 x WAB 450 & 120.33 & 93.33 & 20.23 & 3.63 & 110.00 & 16.50 \\
\hline Morobrekan x IET 1444 & 132.33 & 125.67 & 23.20 & 3.27 & 120.67 & 12.10 \\
\hline Morobrekan x Sakha 102 & 120.67 & 128.33 & 21.17 & 3.00 & 110.33 & 9.67 \\
\hline Morobrekan x WAB 450 & 134.33 & 122.33 & 21.93 & 4.50 & 119.00 & 15.67 \\
\hline L.S.D. 0.05 & 3.37 & 3.27 & 2.66 & 0.25 & 3.63 & 2.11 \\
\hline & 5.29 & 4.20 & 3.42 & 0.33 & 4.66 & 2.71 \\
\hline
\end{tabular}

In addition, the $F_{1}$ mean values of plant height were ranged between 85.33 for (Sakha $105 \mathrm{X}$ Sakha 102) and $128.33 \mathrm{~cm}$ for (Morobrekan X Sakha 102) rice crosses. Plant height of twelve rice crosses was ranged between 85.33 $108.67 \mathrm{~cm}$, which agrees with the target of rice breeders for selected ideal plant height under water stress conditions for resistance to lodging and suitable for mechanical harvesting. Moreover, most of rice crosses were earlier than 100 days and suitable for selecting early maturing rice genotypes. Sakha 105 X IET1444 followed by Sakha 104 X WAB 450-JR-4-1-1 and Giza $178 \times$ WAB 450-JR-4-1-1 were found to be longest panicle, their estimated 
values of panicle length were ranged between $25.17 \mathrm{~cm}$ and $24.17 \mathrm{~cm}$. On the other hand, four crosses, namely; Giza 178 X WAB 450-JR-4-1-1, Sakha 103 X WAB 450-JR-4-1-1, Sakha 104 X WAB 450-JR-4-1-1 and Morobrekan $X$ WAB 450-JR-4-1-1, all included the best general combiner, WAB 450-JR-4$1-1$ as a female parent had heaviest panicle and lighter 100 grains than the heaviest panicle and 100 grains parent (WAB 450-JR-4-1-1). Many number of filled grains were observed for Sakha 104 X WAB 450-JR-4-1-1, Giza 178 X IET 1444 and Giza 178 X WAB 450-JR-4-1-1, but, their estimated values were lower than the value of highest parent (Morobrekan).

Table (2): Continuous

\begin{tabular}{|c|c|c|c|c|c|c|c|}
\hline Genotype & $\begin{array}{c}\text { No. of } \\
\text { panicles/ } \\
\text { plant }\end{array}$ & \begin{tabular}{|c|}
$100-$ \\
grain \\
weight \\
$(\mathrm{g})$
\end{tabular} & $\begin{array}{c}\text { Root } \\
\text { numbers }\end{array}$ & $\begin{array}{c}\text { Root } \\
\text { volume } \\
(\mathrm{mm})\end{array}$ & $\begin{array}{l}\text { Root } \\
\text { length } \\
\text { (cm) }\end{array}$ & $\begin{array}{l}\text { Root } \\
\text { /Shoot } \\
\text { ratio }\end{array}$ & $\begin{array}{c}\text { Grain } \\
\text { yield/ } \\
\text { plant } \\
\text { (g) }\end{array}$ \\
\hline Line 1- Giza 178 & 14.16 & 1.86 & 153.67 & 84.67 & 33.33 & 1.20 & 32.16 \\
\hline Line 2- Sakha 103 & 12.16 & 2.33 & 45.33 & 25.67 & 17.33 & 1.14 & 33.26 \\
\hline Line 3- Sakha 104 & 17.83 & 2.60 & 58.00 & 52.00 & 18.67 & 0.85 & 25.33 \\
\hline Line 4- Sakha 105 & 13.50 & 2.40 & 48.67 & 40.33 & 31.33 & 0.90 & 25.26 \\
\hline Line 5- Morobrekan & & 2.46 & 145.00 & 00 & 37.67 & 0.76 & 21.46 \\
\hline Tester 1- IET 1444 & 50 & 2.26 & 128.33 & 105.33 & 33.33 & 0.79 & 35.26 \\
\hline Tester 2- Sakha 102 & & 2.46 & 53.67 & 27.66 & 18.00 & 0.97 & 30.33 \\
\hline $\begin{array}{l}\begin{array}{l}\text { Tester 3- WAB450-JR-4- } \\
1-1\end{array} \\
\end{array}$ & 17.16 & 3 & 106.33 & 79.67 & 0 & 0.53 & 3 \\
\hline Giza 178 x IET 1444 & 33 & 2.33 & & & & 36 & 36.16 \\
\hline Giza 178 x Sakha 102 & & 2.60 & & & & 56 & 33.90 \\
\hline Giza 178 x WAB 450 & 20.50 & 2.56 & 67 & 67 & 31.00 & 0.94 & 38.83 \\
\hline Sakha 103 x IET 1444 & 16 & 2.50 & 100.33 & 58.67 & 22.67 & 1.29 & 37.00 \\
\hline Sakha 103 x Sakha 102 & 15.16 & 2.63 & 93.67 & 55.00 & 19.00 & 1.13 & 34.96 \\
\hline Sakha $103 \times$ WAB 450 & 20.46 & 2.70 & 72.00 & 40.00 & 25.67 & 1.35 & 33.00 \\
\hline Sakha 104 x IET 1444 & 22.83 & 2.53 & 169.67 & 137.00 & 24.00 & 1.09 & 37.16 \\
\hline Sakha 104 x Sakha 102 & & 2.63 & & & & 90 & 31.33 \\
\hline Sakha $104 \times$ WAB 450 & & 2.63 & 4 & 57 & & 07 & 36.30 \\
\hline Sakha 105 s & 33 & 2.50 & 125.33 & 103.00 & 39.00 & 80 & 38.00 \\
\hline Sakha 105 x Sakha 102 & 16.16 & 2.26 & 73.67 & 55.00 & 28.67 & 1.25 & 29.00 \\
\hline Sakha 105 x WAB 450 & 15.16 & 2.56 & 72.33 & 59.00 & 29.67 & 1.04 & 32.10 \\
\hline Morobrekan x IET 1444 & 26.80 & 2.50 & 173.67 & 148.67 & 41.00 & 0.93 & 25.50 \\
\hline Morobrekan x Sakha 102 & 16.16 & 2.53 & 49.67 & 26.00 & 29.00 & 0.91 & 29.33 \\
\hline Morobrekan x WAB 450 & 19.16 & 2.36 & 164.33 & 141.33 & 39.67 & 0.84 & 21.16 \\
\hline L.S.D. $\mathbf{0 . 0 5}$ & 2.69 & 0.27 & & 4.71 & 3.28 & 0.13 & 2.58 \\
\hline 0.01 & 3.45 & 0.34 & 7.89 & 6.03 & 4.20 & 0.17 & 3.31 \\
\hline
\end{tabular}

Furthermore, the lowest estimated values of sterility \% were showed for Sakha 104 X Sakha 102, Sakha 103 X Sakha 102, Sakha 105 X IET1444 and Sakha $105 X$ Sakha 102, rice crosses. Many number of roots and heavy root volume were exhibited for Morobrekan X IET 1444, Sakha 104 X IET 1444 and Giza 178 X IET 1444, which included IET 1444 as a female parent, it was a good donor for improving these traits. Four rice crosses exhibited the higher root/shoot ratio than the highest parent (Giza 178). Grain yield/plant was found to be higher than the highest parent for two rice crosses, indicating that over-dominance was played a remarkable role in the inheritance of these traits in these counted or mentioned crosses. Moreover, grain yield/plant was 
controlled by partial dominance in Morobrekan X IET 1444 and Morobrekan X WAB 450-JR-4-1-1; their $F_{1}$ mean values were located between the values of their parental lines.

\section{Estimates of general and specific combining ability effects}

General combining ability effects:

The estimates of general combining ability effects consider an important indicator of the potential of parental lines for generating superior breeding populations. A negligible or negative combining ability effect indicates a poor ability to transfer its genetic superiority to hybrids. The largest significant positive values have the largest effects. On the other hand, the largest significant negative values have the smallest effects, except in case of sterility \%, duration (days) and plant height traits. Obviously, Table (3) indicated that Giza 178 and IET 1444 was found to be an overall good general combiners for six traits under consideration including grain yield/pland, root number, root volume and root length. Moreover, IET 1444, Giza 178 and Morobrekan were the good general combiners for root characters, except root/shoot ratio. Sakha 103 was good general combiner for root/shoot ratio and grain yield/plant. Sakha 104 was the best general combiner for panicle length, panicle weight and sterility \%, while, Sakha 105 was the greatest general combiner for earliness, plant height and sterility \%. In addition, Sakha 102 rice tester was good general combiner for improving earliness and sterility \%. While, WAB 450-JR-4-1-1 was the best general combiner for panicle weight and number of filled grains/panicle. However, some parents with high mean values exhibited low GCA effects. Hence, both performances per se and GCA effects should be taken into account for parental selection. The parent Morobrekan, was selected as the best one since it had high mean values for most of root traits and was also a good general combiner for the same traits. Similarly, Sakha 104 and WAB 450-JR4-1-1 rice parents are also judged as being very good parents for some yield components traits.

Table (3): Estimates of general combining ability effects for the studied traits under water stress conditions during 2011 growing season.

\begin{tabular}{|c|c|c|c|c|c|c|}
\hline Genotype & $\begin{array}{l}\text { Duration } \\
\text { (days) }\end{array}$ & $\begin{array}{c}\text { Plant } \\
\text { height }(\mathrm{cm})\end{array}$ & $\begin{array}{c}\text { Panicle } \\
\text { length }(\mathrm{cm})\end{array}$ & $\begin{array}{c}\text { Panicle } \\
\text { weight }(g)\end{array}$ & $\begin{array}{l}\text { No. of filled } \\
\text { grains/ } \\
\text { panicle }\end{array}$ & $\begin{array}{c}\text { Sterility } \\
(\%)\end{array}$ \\
\hline Giza 178 & $3.51^{\star *}$ & $-8.42^{\star *}$ & 0.95 & $0.15^{*}$ & $14.86^{\star *}$ & $2.28^{\star *}$ \\
\hline Sakha 103 & 0.40 & -1.53 & $-1.64^{* *}$ & 0.12 & 0.08 & -0.04 \\
\hline Sakha 104 & $-3.60^{\star *}$ & -2.64 & $0.65^{*}$ & $0.14^{*}$ & -3.35 & $-1.33^{*}$ \\
\hline Sakha 105 & $-7.15^{\star \star}$ & $-11.75^{\star \star}$ & 0.10 & $-0.33^{\star \star}$ & $-11.24^{\star \star}$ & $-1.94^{\star \star}$ \\
\hline Morobrekan & $6.84^{\star \star}$ & $24.35^{\star \star}$ & -0.07 & -0.08 & -0.35 & 1.03 \\
\hline S.E (gi) & 0.76 & 1.10 & 0.60 & 0.05 & 1.89 & 0.47 \\
\hline S.E (gl-gj) & 1.07 & 1.55 & 0.85 & 0.07 & 2.68 & 0.67 \\
\hline IET 1444 & 1.46 & $-3.02^{*}$ & 0.77 & $-0.42^{\star *}$ & -3.28 & -0.22 \\
\hline Sakha 102 & $-6.60^{\star *}$ & -0.48 & -0.74 & $-0.24^{\star *}$ & -3.75 & $-3.98^{* *}$ \\
\hline WAB 450-JR-4-1-1 & $5.13^{* *}$ & $3.51^{*}$ & -0.03 & $0.67^{* *}$ & $7.04^{*}$ & $4.20^{* *}$ \\
\hline S.E (gi) & 0.58 & 0.85 & 0.46 & 0.04 & 1.46 & 0.37 \\
\hline S.E (gt-gj) & 0.83 & 1.20 & 0.65 & 0.06 & 2.07 & 0.52 \\
\hline
\end{tabular}

*and ${ }^{\star \star}$ significant at 0.05 and 0.01 probability levels, respectively. 
It is obvious that none of the parents were found to be good for all studied the traits. Hence, it would be desirable to have multiple crosses involving the parents, viz., IET 1444, Giza 178 and WAB 450-JR-4-1-1, and practicing a selection in the segregating generations to isolate superiorgenotypes. Similar results were obtained previously by Gomez, et al. (2003), Shehata, (2004), Verma and Srivastava (2004), Soroush and Moumeni (2006). El Abd, et al. (2007), Viswanathan satheesh and Thiyagarajan (2008) and Muthurama, et al. (2010).

Table (3): Continuous

\begin{tabular}{|c|c|c|c|c|c|c|c|}
\hline Genotype & $\begin{array}{c}\text { No. of } \\
\text { panicles/ } \\
\text { plant }\end{array}$ & $\begin{array}{c}\text { 100- } \\
\text { grain } \\
\text { weight } \\
\text { (g) }\end{array}$ & $\begin{array}{c}\text { Root } \\
\text { numbers }\end{array}$ & $\begin{array}{c}\text { Root } \\
\text { volume } \\
\text { (mm) }\end{array}$ & $\begin{array}{c}\text { Root } \\
\text { length } \\
\text { (cm) }\end{array}$ & $\begin{array}{c}\text { Root } \\
\text { /Shoot } \\
\text { ratio }\end{array}$ & $\begin{array}{c}\text { Grain } \\
\text { yield/ } \\
\text { plant (g) }\end{array}$ \\
\hline Giza 178 & 1.49 & -0.02 & $34.40^{\star *}$ & $16.35^{\star \star}$ & $3.40^{\star \star}$ & 0.05 & $3.38^{\star *}$ \\
\hline Sakha 103 & -0.40 & 0.08 & $-23.93^{\star \star}$ & $-31.86^{\star \star}$ & $-6.93^{\star \star}$ & $0.19^{\star \star}$ & $2.07^{*}$ \\
\hline Sakha 104 & -0.84 & 0.07 & -4.93 & 4.02 & $-6.71^{\star \star}$ & -0.04 & $2.01^{*}$ \\
\hline Sakha 105 & -0.95 & -0.08 & $-22.15^{\star \star}$ & $-10.75^{\star \star}$ & $3.06^{\star *}$ & -0.03 & 0.11 \\
\hline Morobrekan & 0.70 & -0.05 & $16.62^{\star *}$ & $22.24^{\star \star}$ & $7.17^{\star \star}$ & $-0.16^{\star \star}$ & $-7.58^{\star *}$ \\
\hline S.E (gi) & 0.60 & 0.06 & 3.82 & 2.56 & 0.73 & 0.03 & 0.58 \\
\hline S.E (gl-gj) & 0.85 & 0.08 & 5.40 & 3.62 & 1.04 & 0.04 & 0.82 \\
\hline IET 1444 & $4.68^{\star \star}$ & -0.05 & $35.53^{\star *}$ & $29.37^{\star \star}$ & $3.75^{\star \star}$ & 0.02 & $1.84^{*}$ \\
\hline Sakha 102 & $-3.64^{\star \star}$ & 0.01 & $-25.26^{\star \star}$ & $-19.42^{\star \star}$ & $-4.57^{* \star}$ & -0.01 & -1.21 \\
\hline WAB 450-JR-4-1-1 & -1.04 & 0.04 & $-10.26^{*}$ & $-9.95^{*}$ & 0.82 & -0.01 & -0.63 \\
\hline S.E (gi) & 0.47 & 0.04 & 2.95 & 1.98 & 0.57 & 0.02 & 0.45 \\
\hline S.E (gt-gj) & 0.66 & 0.06 & 4.18 & 2.80 & 0.81 & 0.03 & 0.63 \\
\hline
\end{tabular}

*and ${ }^{\star *}$ significant at 0.05 and 0.01 probability levels, respectively.

\section{Specific combining ability effects}

High specific combining ability effects were caused by the dominance and interaction or epistatic effects (non-fixable genes) that existed between the crossed parents. The same can be used as an index to determine the usefulness of a particular cross-combination in the exploitation of heterosis. As shown in Table (4), 4 crosses out of 15 combinations possessed significant desirable SCA effects for grain yield / plant involving two kind of combinations between the parents of high and low GCA effects, such as Giza $178 \times$ WAB 450-JR-4-1-1 (high x low); Sakha $105 \times$ IET 1444 (low x high), Sakha 104 x WAB 450-JR-4-1-1 (high $x$ low) and Morobrekan $x$ Sakha 102 (low $x$ low), where the majority were derived from former cross-combinations. Moreover, Giza $178 \times$ IET1444 hybrid was the best cross combinations for short plant height, many filled grains/panicle, long roots and high root/shoot ratio. Furthermore, the hybrid, Sakha 104 x WAB 450-JR-4-1-1 was the best cross combinations to improve earliness and increase number of filled grains/panicle as well as low sterility values. While, Morobrekan x WAB 450JR-4-1-1 was the best cross combinations for improving plant height, both roots numbers and their volumes. On the contrary, each of Sakha $103 \times$ IET144 and Sakha105 x WAB 450-JR-4-1-1 rice hybrids were very poor cross combinations, which showed no significant specific combining abilities effects for all the studied traits. 
J. Plant Production, Mansoura Univ., Vol. 3 (12), December, 2012 
However, all cross combinations failed in improving 100-grain weight. On the other hand, Sakha $105 \times$ IET1444 was the greatest cross combinations, it showed significant favorable SCA effects for seven yield components and root traits among them panicle length, sterility \%, number of panicles/plant and root length. The studied hybrids involved all kinds of parental combinations such as high $\mathrm{x}$ high, high $\mathrm{x}$ low and low $\mathrm{x}$ low. This suggests that either additive $\mathrm{x}$ additive, additive $\mathrm{x}$ dominance and/or dominance $\mathrm{x}$ dominance genetic interactions were predominant. The superiority of these crosses may be due to complementary and duplicate type of gene interactions. Hence, these hybrids are expected to produce desirable segregants and could be exploited successfully in breeding programs. Similar findings were reported earlier by El Abd, et al. (2003), Verma and Srivastava (2004), Dhakar and Vinit (2006), Hariprasanna, et al. (2006), Pradhan, et al. (2006), El Abd, et al. (2007), Basbag, et al. (2007), Sarma, et al. (2007), Viswanathan Satheesh and Thiyagarajan (2008) and Muthurama, et al. (2010).

\section{Estimates of heterosis and heterobeltiosis}

A large number of crosses exhibited high estimates of heterosis and heterobeltiosis in a desirable direction for different traits under study. The estimates of heterosis and heterobeltiosis for different traits are presented in table 5. A greater magnitude of heterobeltiosis was ranged between 3.29 and $7.75 \%$ was observed in seven crosses for grain yield /plant. The availability of sufficient hybrid vigor in several crosses in respect of grain yield suggests that a hybrid breeding program could profitably be undertaken in rice under water stress conditions. The results showed that significant heterosis in desirable negative direction was recorded on Sakha 105 x IET1444 rice cross only for earliness, on the other hand, no heterobeltiosis were recorded for earliness in all the studied crosse s. Furthermore, neither heterosis nor heterobeltiosis were observed for plant height in all the studied crosses also.

Thirteen out of 15 crosses had highly significant and positive estimates of heterosis for panicle length and panicle weight, the highest estimated values (34.82 and 32.43\%) were exhibited in Sakha 105 x IET1444 and Sakha 104 x IET 1444 rice crosses, respectively, otherwise, the lowest estimated values (5.45 and 2.64\% were recorded in Morobrekan x IET1444 and Sakha $105 \times$ Sakha 102 rice crosses, respectively. While the highest estimated values of heterobeltiosis (32.45 and 19.51\%) were observed in Sakha $105 \times$ IET1444 and Sakha $104 \times$ IET1444 for panicle length and panicle weight, respectively. Highly significant and negative estimates of heterosis and heterobeltiosis were obtained in 4 and 2 crosses for sterility \%, respectively, the most important crosses for reducing sterile grains were Sakha 103 x Sakha 102 and Sakha 104 x Sakha 102. 
Table (5): Estimates of heterosis as a deviation from mid-parents (MP) and better-parents (BP) for some root and yield related traits in the studied rice crosses under water stress conditions during 2011 growing season.

\begin{tabular}{|c|c|c|c|c|c|c|c|c|c|c|}
\hline \multirow[t]{2}{*}{ Genotype } & \multicolumn{2}{|c|}{$\begin{array}{l}\text { Duration } \\
\text { (days) }\end{array}$} & \multicolumn{2}{|c|}{\begin{tabular}{|c|} 
Plant Height \\
(cm)
\end{tabular}} & \multicolumn{2}{|c|}{$\begin{array}{c}\text { Panicle } \\
\text { Length (cm) }\end{array}$} & \multicolumn{2}{|c|}{$\begin{array}{c}\text { Panicle } \\
\text { weight }(g)\end{array}$} & \multicolumn{2}{|c|}{ Sterility (\%) } \\
\hline & M.P & B.P & M.P & B.P & M.P & B.P & M.P & B.P & M.P & B.P \\
\hline Giza 178 x IET 1444 & $8.29^{\star \star}$ & $.58^{\star \star}$ & 39 & 2.40 & $6.66^{* *}$ & $16.66^{* *}$ & $26.50^{* *}$ & $5.00^{\star *}$ & $99^{\star \star}$ & $0.92^{\star \star}$ \\
\hline $\begin{array}{l}\text { Giza } 178 \times \text { Sakha } \\
102\end{array}$ & $4.34^{\star *}$ & $5.13^{* *}$ & $12.66^{* *}$ & $14.61^{* *}$ & $15.33^{\star *}$ & $9.84^{\star *}$ & $-4.39^{* *}$ & $-6.66^{\star *}$ & $76.65^{\star \star}$ & $113.46^{* *}$ \\
\hline $\begin{array}{|llll|}\text { Giza } & 178 & x & \text { WAB } \\
\end{array}$ & \begin{tabular}{|l|l|} 
& $11.76^{* *}$ \\
\end{tabular} & $18.75^{\star *}$ & $73^{* *}$ & $9.80^{* *}$ & $29.46^{\star *}$ & $27.19^{\star *}$ & $24.77^{\star *}$ & $11.90^{\star *}$ & $14.46^{\star \star}$ & $102.26^{* *}$ \\
\hline $\begin{array}{|llll|}\begin{array}{l}\text { Sakha } \\
1444\end{array} & 103 & x & \text { IET } \\
\end{array}$ & $7^{\star \star}$ & $10.77^{\star *}$ & $10.64^{* *}$ & $16.40^{\star *}$ & $23.30^{* *}$ & $11.40^{\star \star}$ & $23.48^{\star \star}$ & $10.84^{\star \star}$ & $66.27^{\star \star}$ & $119.13^{\star *}$ \\
\hline $\begin{array}{l}\text { Sakha } 103 \times \text { Sakha } \\
102\end{array}$ & $3.75^{\star \star}$ & $22^{*}$ & ** & $43^{\star *}$ & $.55^{\star *}$ & $-3.49^{* *}$ & ** & ** & ** & $0^{* *}$ \\
\hline $\begin{array}{l}\text { Sakha } 103 \times \text { x WAB } \\
450\end{array}$ & $9.26^{\star *}$ & $16.46^{\star *}$ & $02^{\star *}$ & $92^{\star \star}$ & $80^{* *}$ & 5** & $0^{* *}$ & ** & $*^{* *}$ & $22^{\star \star}$ \\
\hline $\begin{array}{|llll|}\begin{array}{l}\text { Sakha } \\
1444\end{array} & 104 & x & \text { IET } \\
\end{array}$ & 2.24 & $7.66^{\star *}$ & $30^{\star *}$ & $11.60^{* *}$ & $21.40^{\star *}$ & $21.40^{* *}$ & $32.43^{\star \star}$ & $19.51^{* \star}$ & 90. & $96^{* *}$ \\
\hline $\begin{array}{l}\text { Sakha } 104 \times \text { Sakha } \\
102\end{array}$ & 2.68 & $3.92^{*}$ & $5^{*}$ & 4.46 & $6.16^{\star *}$ & 1.11 & $7^{\star \star}$ & $3.80^{\star *}$ & $3^{\star *}$ & $4^{\star \star}$ \\
\hline $\begin{array}{l}\text { Sakha } 104 \times \text { X WAB } \\
450\end{array}$ & 0.13 & $5.89^{\star \star}$ & $4.19^{\star *}$ & $27.84^{\star \star}$ & $29.64^{* *}$ & $27.36^{* *}$ & $30.76^{\star *}$ & $7.93^{\star \star}$ & $9.21^{* *}$ & $50^{\star *}$ \\
\hline $\begin{array}{|llll|}\begin{array}{l}\text { Sakha } \\
1444\end{array} & 105 & x & \text { IET } \\
\end{array}$ & $-3.69 *$ & 03 & $51^{* *}$ & $14.04^{\star *}$ & $34.82^{\star *}$ & $32.45^{\star *}$ & $25.33^{\star \star}$ & $11.90^{* \star}$ & $-25.84^{* \star}$ & 1.85 \\
\hline $\begin{array}{l}\text { Sakha } 105 \times \text { Sakha } \\
102\end{array}$ & 1.81 & 12 & 58 & $3^{\star *}$ & $8.98^{\star *}$ & 2.06 & $2.64^{\star *}$ & $-7.61^{\star *}$ & $-11.16^{\star \star}$ & $25.00^{* *}$ \\
\hline $\begin{array}{l}\text { Sakha } 105 \times \text { X WAB } \\
450\end{array}$ & $4.55^{\star \star}$ & $9.72^{* *}$ & $4.29^{\star *}$ & $19.14^{\star *}$ & $20.72^{\star \star}$ & $10.36^{\star *}$ & $9.52^{* *}$ & $-13.49^{* *}$ & $51.94^{\star *}$ & $74.91^{* *}$ \\
\hline $\begin{array}{l}\text { Morobrekan } x \text { IET } \\
1444\end{array}$ & $6.00^{* *}$ & $4^{\star *}$ & $11.70^{* *}$ & $50.80^{\star \star}$ & $5.45^{\star *}$ & $-7.20^{* *}$ & $10.73^{\star \star}$ & $-11.71^{* *}$ & ** & 12 \\
\hline $\begin{array}{l}\text { Morobrekan } \\
\text { Sakha } 102\end{array}$ & 2.69 & $9.36^{\star *}$ & $10.95^{\star \star}$ & $43.12^{\star \star}$ & $-7.97^{\star \star}$ & $-15.33^{\star *}$ & $-16.66^{* *}$ & $-18.91^{* *}$ & $41.80^{\star \star}$ & $85.89^{* *}$ \\
\hline $\begin{array}{l}\text { Morobrekan x WAB } \\
450\end{array}$ & $7.18^{\star \star}$ & ** & $*^{* *}$ & $2^{\star \star}$ & 1.23 & $-12.26^{\star *}$ & $13.92^{\star *}$ & $4^{\star *}$ & $15.62^{\star *}$ & $85.77^{\star *}$ \\
\hline \begin{tabular}{|ll} 
L.S.D & 0.05 \\
\end{tabular} & 2.91 & 3.37 & 2.84 & 3.27 & 2.31 & 2.66 & 0.22 & 0.25 & 1.83 & 2.11 \\
\hline 0.01 & 3.74 & 5.29 & 3.64 & 4.20 & 2.96 & 3.42 & 0.28 & 0.33 & 2.35 & 2.71 \\
\hline
\end{tabular}

*and ${ }^{* *}$ significant at 0.05 and 0.01 probability levels, respectively.

Obviously, (Table 5) shows that the cross, Sakha $104 \times$ WAB 450JR-4-1-1 exhibited highest estimate of heterosis (33.96\%) for number of filled grains/panicle followed by Giza 178 x IET1444 (20.41\%), while, the highest estimate of heterobeltiosis was recorded on Sakha $103 \times$ Sakha 102 $(15.72 \%)$ for the same trait. For number of panicles/plant, further, 13 out of 15 crosses were recorded significant heterosis in a desirable positive direction, their estimated values were ranged between (6.71 and 61.45\%) in Morobrekan x Sakha 102 and Sakha 105 x IET1444 rice crosses, respectively. On the other hand 11 out of 15 studied crosses showed significant heterobeltiosis for number of panicles/ plant, their estimated values were $\mathrm{d}$ between (5.50 and 44.86\%) in Morobrekan x WAB 450 and Morobrekan x IET1444 rice crosses, respectively. Furthermore, highly significant and positive estimates of heterosis and heterobeltiosis were recorded on 11 and 8 rice crosses, the highest estimated values were 
reported on Giza 178 x Sakha $102(20.00 \%)$ and Sakha 103 x IET144 $(7.14 \%)$ for 100 -grain weight, respectively. Eleven rice crosses exhibited highly significant and positive heterosis, when it was measured as a deviation from mid-parent for grain yield/plant, the highest estimated value was recorded on Morobrekan x Sakha $102(28.09 \%)$, while, only seven crosses exhibited highly significant and positive estimates of heterobeltiosis for grain yield/plant.

Table (5): Continuous

\begin{tabular}{|c|c|c|c|c|c|c|c|c|}
\hline \multirow[t]{2}{*}{ Genotype } & \multicolumn{2}{|c|}{$\begin{array}{c}\text { No. of filled } \\
\text { grains/ panicle }\end{array}$} & \multicolumn{2}{|c|}{$\begin{array}{c}\text { No. of Panicles/ } \\
\text { plant }\end{array}$} & \multicolumn{2}{|c|}{$\begin{array}{c}\text { 100- grain weight } \\
(\mathrm{g})\end{array}$} & \multicolumn{2}{|c|}{$\begin{array}{l}\text { Grain yield/ } \\
\text { Plant }(g)\end{array}$} \\
\hline & M.P & B.P & M.P & B.P & M.P & B.P & M.P & B.P \\
\hline Giza 178 x IET 1444 & $20.41^{* *}$ & 7.44 & $52.04^{\star \star}$ & $34.23^{* \star}$ & $12.90^{* \star}$ & $2.94^{* *}$ & $7.26^{\star \star}$ & 2.55 \\
\hline $\begin{array}{l}\text { Giza } 178 \times \text { x Sakha } \\
102\end{array}$ & $8.96^{*}$ & 1.86 & $45.75^{\star \star}$ & $35.29^{* *}$ & $20.00^{* *}$ & $5.40^{* *}$ & $8.48^{* *}$ & $5.38^{* *}$ \\
\hline Giza $178 \times$ WAB 450 & 4.43 & 2.56 & $30.85^{\star \star}$ & $19.41^{* *}$ & $4.76^{\star *}$ & $-15.38^{\star \star}$ & $10.79^{\star *}$ & 2.37 \\
\hline \begin{tabular}{|llll}
$\begin{array}{l}\text { Sakha } \\
1444\end{array}$ & 103 & $x$ & IET \\
\end{tabular} & 0.31 & -6.23 & $51.08^{\star *}$ & $25.22^{* *}$ & 8.6 & $7.14^{\star *}$ & ** & $4.91^{* *}$ \\
\hline $\begin{array}{l}\text { Sakha } 103 \times \text { Sakha } \\
102\end{array}$ & $17.46^{\star \star}$ & $15.72^{* *}$ & $24.82^{* *}$ & $-14.95^{\star *}$ & $9.72^{* *}$ & $6.75^{\star *}$ & $9.95^{* *}$ & $5.11^{* *}$ \\
\hline $\begin{array}{l}\text { Sakha } 103 \times \text { WAB } \\
450\end{array}$ & -4.26 & $0.76^{\star \star}$ & $.54^{\star *}$ & $19.22^{* *}$ & ** & $8^{\star \star}$ & $-7.30^{\star *}$ & $-13.00^{\star *}$ \\
\hline \begin{tabular}{|llll}
$\begin{array}{l}\text { Sakha } \\
1444\end{array}$ & 104 & $x$ & IET \\
\end{tabular} & $14.97^{\star \star}$ & 5.42 & $25.68^{* *}$ & $23.42^{\star *}$ & $4.11^{\star \star}$ & $-2.56^{\star *}$ & $22.66^{\star *}$ & $5.38^{\star *}$ \\
\hline $\begin{array}{l}\text { Sakha } 104 \times \text { Sakha } \\
102\end{array}$ & -0.17 & $\mid-12.53^{\star \star}$ & 1.22 & $-14.95^{\star \star}$ & $3.80^{\star \star}$ & $1.15^{\star *}$ & $12.57^{\star \star}$ & $3.30^{* *}$ \\
\hline $\begin{array}{l}\text { Sakha } 104 \times \text { WAB } \\
450\end{array}$ & $33.96^{* *}$ & $9.23^{*}$ & $11.42^{* *}$ & $9.34^{\star *}$ & ** & -13 & 14. & $3.29^{*}$ \\
\hline $\begin{array}{|llll|}\begin{array}{l}\text { Sakha } \\
1444\end{array} & 105 & x & \text { IET } \\
\end{array}$ & $14.44^{* *}$ & 6.10 & $1.45^{\star \star}$ & $39.63^{\star *}$ & 7.1 & $4.16^{\star *}$ & $25.55^{\star *}$ & $7.75^{\star *}$ \\
\hline $\begin{array}{l}\text { Sakha } 105 \times \text { Sakha } \\
102\end{array}$ & 6.73 & -5.50 & $26.13^{\star \star}$ & $19.75^{\star *}$ & $.84^{\star *}$ & $-8.10^{\star *}$ & $4.31^{* *}$ & $-4.39^{* *}$ \\
\hline $\begin{array}{l}\text { Sakha } 105 \times \text { WAB } \\
450\end{array}$ & 2.80 & ** & 08 & ** & -5.5 & -15. & 1.58 & $-15.37^{\star \star}$ \\
\hline \begin{tabular}{|lll}
$\begin{array}{l}\text { Morobrekan } \\
1444\end{array}$ & $x$ & IET \\
\end{tabular} & -5.85 & $\left|-23.62^{\star *}\right|$ & $46.18^{* *}$ & $44.86^{* *}$ & 5.6 & $1.35^{\star *}$ & 0.52 & $-27.69^{\star \star}$ \\
\hline \begin{tabular}{|l|} 
Morobrekan \\
Sakha 102 \\
\end{tabular} & $-17.35^{\star *}$ & $\left|-30.16^{\star *}\right|$ & $6.71^{* *}$ & $-11.01^{* *}$ & $2.90^{* *}$ & $2.70^{* *}$ & $28.09^{* *}$ & $-3.29^{*}$ \\
\hline $\begin{array}{l}\text { Morobrekan x WAB } \\
450\end{array}$ & -17 & -24 & 8. & ** & $3^{* *}$ & -21 & $2^{\star *}$ & $-44.20^{* *}$ \\
\hline \begin{tabular}{|ll} 
L.S.D & 0.05 \\
\end{tabular} & 3.15 & & & & & & 20 & 2.50 \\
\hline 0. & 03 & 56 & 3.08 & 45 & 0.8 & 0.3 & 2.87 & 3.31 \\
\hline
\end{tabular}

With regarding of roots numbers and root volume, (Table 5) demonstrated that the estimates of heterosis were found to be highly significant and positive in 10 and 11 crosses, out of them, the highest estimated values were recorded on Sakha 103 x Sakha $102(89.22 \%)$ and Sakha 104 x Sakha 102 (137.65\%), respectively. The highest estimates of heterosis, when it measured as a deviation from better parent were observed on Sakha 104 x Sakha $102(81.03 \%)$ and Sakha 103 x Sakha $102(98.79 \%)$ for root number and root volume, respectively. On the other hand, desirable heterosis was found among all the studied crosses for root length, which exhibited significant or highly significant estimates in positive direction, except 
two crosses namely, Sakha 103 x IET 1444, and Sakha 104 x IET 1444. Moreover, out of fifteen studied crosses, nine crosses, exhibited highly significant and positive estimates of heterobeltiosis for root length, while the most of other remaining crosses recorded highly significant heterobeltiosis in negative direction for such trait. Sakha $103 \times$ WAB 450-JR-4-1-1 followed by Sakha 104 x WAB 450-JR-4-1-1 and Sakha 105 x WAB 450-JR-4-1-1 were the best crosses for improving root/shoot ratio, all of them included WAB 450JR-4-1-1 as a female parent and one of Egyptian rice variety as a male parent, suggesting the importance of using the Egyptian rice variety as donors in any successful Sakha 103 X Sakha 102 and Sakha 104 X Sakha 102 can be rated as the best crosses breeding program. From the foregoing discussion, it may be concluded that the crosses, Sakha $103 \times$ Sakha 102 and Sakha $104 \times$ IET 1444 based on their heterosis in most of the studied traits included grain yield.

Table (5): Continuous.

\begin{tabular}{|c|c|c|c|c|c|c|c|c|}
\hline \multirow[t]{2}{*}{ Genotype } & \multicolumn{2}{|c|}{ Root Number } & \multicolumn{2}{|c|}{ Rot Volume $(\mathrm{cm})$} & \multicolumn{2}{|c|}{$\begin{array}{l}\text { Root Length } \\
\text { (cm) }\end{array}$} & \multicolumn{2}{|c|}{$\begin{array}{c}\text { Root /Shoot } \\
\text { Ratio }\end{array}$} \\
\hline & M.P & B.P & M.P & B.P & M.P & B.P & M.P & B.P \\
\hline Giza 178 x IET 1444 & $21.74^{\star *}$ & $11.71^{* *}$ & $21.05^{\star \star}$ & $9.17^{\star \star}$ & $17.00^{\star *}$ & $17.00^{* *}$ & $36.68^{* *}$ & $13.33^{* *}$ \\
\hline $\begin{array}{llll}\text { Giza } & 178 & \text { x } & \text { Sakha } \\
102 & & & \\
\end{array}$ & $10.61^{\star *}$ & $-25.37^{\star *}$ & $56.08^{\star *}$ & 3.54 & $10.39^{* *}$ & $-15.00^{\star *}$ & $-2.60^{\star *}$ & $-11.67^{\star *}$ \\
\hline 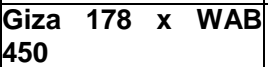 & $18.97^{\star *}$ & 0.65 & $16.43^{\star *}$ & $12.99^{* *}$ & $10.06^{* *}$ & $-7.00^{* *}$ & $8.67^{* *}$ & $-21.67^{\star *}$ \\
\hline $\begin{array}{|llll|}\begin{array}{l}\text { Sakha } \\
1444\end{array} & 103 & x & \text { IET } \\
\end{array}$ & $15.54^{\star *}$ & $-21.81^{\star *}$ & $-10.43^{\star *}$ & $-44.30^{\star *}$ & $-10.53^{\star \star}$ & $-32.00^{* *}$ & $33.68^{* *}$ & $13.16^{\star *}$ \\
\hline $\begin{array}{l}\text { Sakha } 103 \times \text { Sakha } \\
102\end{array}$ & $89.22^{\star \star}$ & $74.53^{\star \star}$ & $106.25^{\star *}$ & $98.79^{* \star}$ & $7.55^{\star \star}$ & $5.56^{\star *}$ & $6.77^{\star *}$ & $-0.88^{* *}$ \\
\hline $\begin{array}{l}\text { Sakha } 103 \times \text { WAB } \\
450\end{array}$ & -5.05 & $-32.28^{* *}$ & $-24.05^{\star \star}$ & $-49.79 * *$ & $27.27^{\star \star}$ & $11.59^{* *}$ & $61.68^{\star *}$ & $18.42^{* *}$ \\
\hline $\begin{array}{|llll|}\begin{array}{l}\text { Sakha } \\
1444\end{array} & 104 & x & \text { IET } \\
\end{array}$ & $82.11^{* *}$ & $32.20^{\star *}$ & $74.15^{\star \star}$ & $30.06^{\star *}$ & $-7.69^{\star *}$ & $-28.00^{* *}$ & $32.93^{* *}$ & $28.24^{\star *}$ \\
\hline $\begin{array}{l}\text { Sakha } 104 \times \text { Sakha } \\
102\end{array}$ & $88.05^{\star *}$ & $81.03^{\star *}$ & $137.65^{\star *}$ & $82.05^{\star \star}$ & $3.64^{\star *}$ & 1.79 & $-0.73^{\star \star}$ & $-7.17^{\star \star}$ \\
\hline $\begin{array}{l}\text { Sakha } 104 \times \text { WAB } \\
450\end{array}$ & $-41.17^{\star *}$ & $-54.54^{* *}$ & $-54.93^{* *}$ & $-62.76^{\star *}$ & $20.00^{\star *}$ & $8.70^{\star \star}$ & $54.59^{* *}$ & $25.49^{* *}$ \\
\hline $\begin{array}{|llll|}\begin{array}{l}\text { Sakha } \\
1444\end{array} & 105 & x & \text { IET } \\
\end{array}$ & $41.61^{\star *}$ & -2.33 & $41.41^{\star *}$ & -2.21 & $20.62^{* \star}$ & $17.00^{\star *}$ & $-5.51^{\star *}$ & $-11.44^{\star *}$ \\
\hline $\begin{array}{l}\text { Sakha } 105 \times \text { Sakha } \\
102\end{array}$ & $43.97^{\star *}$ & $37.26^{\star \star}$ & $61.76^{\star \star}$ & $36.36^{\star \star}$ & $16.22^{\star *}$ & $-8.51^{\star *}$ & $33.69^{\star *}$ & $28.67^{\star \star}$ \\
\hline $\begin{array}{l}\text { Sakha } 105 \times \text { WAB } \\
450\end{array}$ & $-21.23^{\star *}$ & $-31.97^{\star \star}$ & $-4.95^{\star}$ & $-25.94^{\star \star}$ & $15.96^{\star \star}$ & $-5.32^{\star \star}$ & $73.06^{\star *}$ & $15.87^{\star *}$ \\
\hline $\begin{array}{llll}\begin{array}{l}\text { Morobrekan } x \\
1444\end{array} \\
\end{array}$ & $27.07^{\star \star}$ & $19.77^{\star \star}$ & $29.08^{\star *}$ & $18.93^{\star *}$ & $15.49^{* *}$ & $8.85^{\star \star}$ & $20.60^{\star *}$ & $18.87^{\star \star}$ \\
\hline \begin{tabular}{|l|} 
Morobrekan \\
Sakha 102
\end{tabular} & $-50.00^{* *}$ & $-65.74^{* *}$ & $-65.93^{* *}$ & $-79.20^{* *}$ & $4.19^{\star *}$ & $-23.01^{\star *}$ & $4.60^{* *}$ & $-6.83^{\star *}$ \\
\hline $\begin{array}{l}\text { Morobrekan x WAB } \\
450\end{array}$ & $30.76^{\star *}$ & $13.33^{* *}$ & $38.11^{\star *}$ & $13.06^{\star *}$ & $30.76^{\star \star}$ & $5.31^{* *}$ & $30.93^{* *}$ & $10.92^{* *}$ \\
\hline $\begin{array}{|ll|}\text { L.S.D } & 0.05 \\
\end{array}$ & 5.33 & 6.16 & 4.07 & 4.71 & 2.84 & 3.28 & 0.11 & 0.13 \\
\hline 0.01 & 6.84 & 7.89 & 5.22 & 6.03 & 3.64 & 4.20 & 0.15 & 0.17 \\
\hline
\end{tabular}

${ }^{*}$ and ${ }^{* *}$ significant at $\mathbf{0 . 0 5}$ and 0.01 probability levels, respectively.

Thus, it can be exploited in subsequent generations to improve most of the studied traits. Similar results were reported by several scientists such as, El 
Abd, et al. (2003), Verma and Srivastava (2004), Khoyumthem, et al. (2005), Basbag, et al. (2007), El Abd, et al. (2007), Ganapathy and Ganesh (2008), Amudha, et al. (2010) and Muthuramu, et al. (2010).

\section{Estimates of genetic parameters for the studied traits}

It is evident from Table (6) that the dominance genetic variance was greater than additive genetic variance for all the studied traits except duration, plant height, number of panicles / plant and root length which controlled by additive genetic variance. The highest estimated values of environmental variance were recorded for number of roots / plant followed by root volume and number of filled grains/panicle traits. On the other hand, high heritability coupled with moderate to high expected genetic advance were noted for root volume followed by number of roots / plant and plant height traits, revealing substantial contribution of additive variance in phenotypic expression, and indicating the effectiveness of selection in early generation to improve these traits. Falconer and Mackay (1996) demonstrated that the lower narrow sense heritability was caused by low additive effects and high dominant gene action. These results are in harmony with the combining ability analysis. The highest estimated values of narrow sense heritability were exhibited for plant height and duration (days), on the contrary, the lowest values were observed for 100-grain weight, root/shoot ratio, panicle length and number of filled grains/panicle. Moreover, the ratio of GCA and SCA variances was greater than unity for all the traits studied that revealed the preponderance of non-additive gene action over the additive gene action for all traits studied. The results suggest that improvement in these traits may be obtained via heterosis breeding or by single plant selection in later generations following hybridization or intermating of selected segregants through recurrent selection. Similar results were observed previously by Mndal and Dana (1994), Verma and Srivastava (2004), Bagheri, et al. (2005), Saxena, et al. (2005), Manickavelu, et al. (2006), pradhan, et al. (2006) and Sarma, et al. (2007).

Table (6): Estimates of genetic parameters for the studied traits under water stress conditions during 2011 growing season.

\begin{tabular}{|l|c|c|c|c|c|c|}
\hline \multicolumn{1}{|c|}{ Genetic Parameter } & $\begin{array}{c}\text { duration } \\
\text { (days) }\end{array}$ & $\begin{array}{c}\text { Plant } \\
\text { Height } \\
\text { (cm) }\end{array}$ & $\begin{array}{c}\text { Panicle } \\
\text { Length } \\
\text { (cm) }\end{array}$ & $\begin{array}{c}\text { Po. of } \\
\text { Peight (g) }\end{array}$ & $\begin{array}{c}\text { filled } \\
\text { grains/ } \\
\text { panicle }\end{array}$ & $\begin{array}{c}\text { Sterility } \\
\text { (\%) }\end{array}$ \\
\hline Dominance Variance & 5.20 & 27.29 & 0.99 & 0.09 & 150.34 & 5.87 \\
\hline Additive Variance & 10.17 & 35.72 & 0.08 & 0.05 & 7.31 & 2.48 \\
\hline Genetic Variance & 15.37 & 63.02 & 1.07 & 0.14 & 157.65 & 8.35 \\
\hline Environment Variance & 5.20 & 10.92 & 3.26 & 0.02 & 32.35 & 2.05 \\
\hline Phenotypic Variance & 4.84 & 8.59 & 2.08 & 0.41 & 13.78 & 3.22 \\
\hline Ratio of gca Var. to sca Var. & 2.25 & 2.30 & 1.08 & 1.52 & 1.04 & 1.42 \\
\hline Narrow sense heritability & 43.37 & 48.31 & 1.91 & 28.82 & 3.84 & 23.86 \\
\hline Broad sense heritability & 77.82 & 85.22 & 24.81 & 83.80 & 82.97 & 80.26 \\
\hline Expected Genetic Advance & 6.45 & 15.34 & 5.02 & 20.74 & 20.41 & 50.78 \\
\hline
\end{tabular}


Table (6): Continuous

\begin{tabular}{|l|c|c|c|c|c|c|c|}
\hline \multicolumn{1}{|c|}{ Genetic Parameters } & $\begin{array}{c}\text { No. of } \\
\text { Panicles// } \\
\text { plant }\end{array}$ & $\begin{array}{c}\mathbf{1 0 0} \\
\text { grain } \\
\text { weight } \\
\mathbf{( g )}\end{array}$ & $\begin{array}{c}\text { Root } \\
\text { Number }\end{array}$ & $\begin{array}{c}\text { Rot } \\
\text { Volume } \\
\text { (cm) }\end{array}$ & $\begin{array}{c}\text { Root } \\
\text { Length } \\
\text { (cm) }\end{array}$ & $\begin{array}{c}\text { Root } \\
\text { /shoot } \\
\text { Ratio }\end{array}$ & $\begin{array}{c}\text { Grain } \\
\text { yield/ } \\
\text { Plant } \\
\text { (g) }\end{array}$ \\
\hline Dominance Variance & 2.41 & 0.002 & 1313.06 & 1308.50 & 8.03 & 0.027 & 10.07 \\
\hline Additive Variance & 2.63 & 0.001 & 144.45 & 67.52 & 9.35 & 0.001 & 2.90 \\
\hline Genetic Variance & 5.05 & 0.003 & 1457.52 & 1376.02 & 17.38 & 0.027 & 12.97 \\
\hline Environment Variance & 3.32 & 0.033 & 131.38 & 59.14 & 4.92 & 0.008 & 3.06 \\
\hline Phenotypic Variance & 2.89 & 0.190 & 39.86 & 37.88 & 4.72 & 0.190 & 4.01 \\
\hline Ratio of gca Var. to sca Var. & 2.08 & 1.044 & 1.11 & 1.05 & 2.16 & 1.020 & 1.28 \\
\hline Narrow sense of Heritability & 31.45 & 0.362 & 9.09 & 4.70 & 41.92 & 1.535 & 18.11 \\
\hline Broad sense of Heritability & 60.31 & 8.559 & 91.73 & 95.87 & 77.91 & 76.61 & 80.88 \\
\hline Expected Genetic Advance & 19.52 & 1.34 & 71.35 & 96.32 & 26.69 & 29.94 & 21.06 \\
\hline
\end{tabular}

\section{REFERENCES}

Abd Allah, A. A. 2004 a. Genetic studies on leaf rolling and some root traits under drought conditions in rice (Oryza sativa L.). African Journal of Biotechnology. 8:(22): 6241-6248.

Abd-Allah, A. A. 2004 b. A breeding study on drought tolerance in rice (Oryza sativa L.). Egyptian J. of Agric. Res. 82(1): 149-165.

Allard, R. W. 1999. Principles of Plant Breeding, 2nd edition, New York, John Wiley and Sons, U.S.A.

Amudha, K., K. Thiyagarajan, S. Robin, S. J. K. Prince, R. Poornima and K. K. Suji. 2010. Heterosis under aerobic condition in hybrid rice. Electronic Journal of Plant Breeding. 1: 4, 769-775.

Amudha, K., S. Arumugachamy and K. Thiyagarajan. 2007. Studies on biparental progenies of rice under water stress condition. Indian Journal of Agricultural Research. 41: 4, 272-276.

Bagheri, A. H., G. A. Nematzadeh, S. A. Peighambari and M. Noroozi. 2005. A study of combining ability and gene effect in rice cultivars through line/tester analysis. Iranian Journal of Agricultural Sciences. 36(4): 947953.

Basbag, S., R. Ekinci and O. Gencer. 2007. Combining ability and heterosis for earliness characters in line $x$ tester population of (Gossypium hirsutum L.). Hereditas. 144: 185-190.

Ceyhan, E. 2003. Determination of some agricultural characters and their heredity through line $x$ tester method in pea parents and crosses. Selcuk Univ., Graduate School Nat. Appl. Sci. p. 103.

Dewey, D. R. and H. K. Lu. 1959. A correlation and path coefficient analysis of components of created wheat grass seed production. Agron. J. 51: $515-518$.

Dhakar, J. M. and V. Vinit. 2006. Combining ability analysis in rice (Oryza sativa L.). Crop Research Hisar. 31(3): 378-379.

Dhillon, B.S. 1975. The application of partial diallel crosses in plant breedingA review. Crop Improve. 2: 1-7. 
Dudley, J. W. and R. H Moll. 1969. Interpretation and use of estimates of heritability and genetic advance in plant breeding. Crop Science 9: 257 $-262$.

El Abd, A. B., A. A. Abd Allah and A. A. El-Hissewy. 2003. Studies on combining ability and heterosis for some physiological characters in rice (Oryza sativa L.). Proc. 10th National Conference of Agronomy, Fac. of Environ. Sci., El-Arish, Suez Canal Univ., Egypt, 7-10, 81-93.

El Abd, A. B., A. A. Abd Allah, S. M. Shehata, A. S. M. Abd El-Lateef and B. A. Zayed. 2007. Heterosis and combining ability for yield and its components and some root characters in rice under water stress conditions. Proc. Fifth Plant Breeding Conference, May 27. Egypt. J. Plant Breeding, Special Issue, Vol. 11 (2): 593-609.

Falconer, D. S. and F. C. Mackey (1996). Introduction to Quantitative Genetics. Fourth Edition. Longman. New York.

Fehr, W.R. 1987. Heterosis. In: Principles of cultivar development; Theory and techniques (Vol. 1) MacMillan Publishing Company, New York, pp: 115.

Fonsecca, S. and F. L. Patterson. 1968. Hybrid vigour in seven-parent diallel cross in common wheat (T. aestivum L.). Crop Sci. 2: 85-88.

Ganapathy, S. and S. K. Ganesh. 2008. Heterosis analysis for physiomorphological traits in relation to drought tolerance in rice. (Oryza sativa L.). World J. of Agric. Sci. 4(5): 623-629.

Gomez, S. M. and A. Kalamani. 2003. Scope of landraces for future drought tolerance breeding programme in rice (Oryza sativa L.). Plant Archives. 3: $1,77-79$.

Gomez, S. M., P. Rangasamy and N. Nadarajan. 2003. Assessing the best combiners in rice (Oryza sativa L.) suitable for drought prone areas of Tamil Nadu. Research on Crops. 4: 1, 79-84.

Hariprasanna, K., F. U. Zaman, A. K. Singh and S. M. S. Tomar. 2006. Analysis of combining ability status among parents and hybrids in rice (Oryza sativa L.). Indian Journal of Genetics and Plant Breeding. 66(1): 28-30.

Jodon, N. E. 1938. Experiments on artificial hybridization of rice. J. Amer. Soc. Agron., 30: $249-305$.

Kempthorne, O. 1957. An introduction to genetic statistics. John Wiley \& Sons.

Khoyumthem, P., P. R. Sharma, N. B. Singh and M. R. K. Singh. 2005. Heterosis for grain yield and its component characters in rice (Oryza sativa L.). Environment and Ecology. 23S (Special 4): 687-691.

Le Clerg, E. L., W. H. Leonard and A. G. Clark. 1962. Field Plot Technique. Burgress Pub. Co., Minnesota, U. S. A.

Mandal, N. and I. Dana. 1994. Genetic information on root type in drought resistant rice (Oryza sativa L.). Environment and Ecology. 12: 2, 360362.

Manickavelu, A., R. P. Gnanamalar, N. Nadarajan and S. K. Ganesh. 2006. Genetic variability studies on different genetic populations of rice under drought condition. Journal of Plant Sciences. 1: 4, 332-339. 
Matzinger, D. F., T. J. Mannand, and C. C. Cockerham. 1962. Diallel cross in Nicotiana tabacum. Crop. Sci., 2: 238-286.

Muthuramu, S., S. Jebaraj, R. Ushakumari and M. Gnanasekaran. 2010. Estimation of combining ability and heterosis for drought tolerance in different locations in rice (Oryza sativa L.). Electronic Journal of Plant Breeding. 1: 5, 1279-1285.

Pradhan, S. K., L.K. Boss and J. Meher. 2006. Studies on gene action and combining ability analysis in Basmati rice. Journal of Centeral European Agriculture, Vol. 7 (2): 267-272.

Prasad, S. R., R. Prakash, C. M. Sharma and M. F. Itaque. 1981. Genotypic and phenotypic variability in quantitative characters in Oats. Indian Journal of Agricultural Science 51: 480-482.

Sarma, M. K., A. K. Sharma, R. K. Agrawal and A. K. Richharia. 2007. Combining ability and gene action for yield and quality traits in Ahu rices of Assam. Indian Journal of Genetics and Plant Breeding. 67: 3, 278-280.

Saxena, R. R., R. R. Saxena, N. K. Motiramani, S. S. Nichal and R. K. Sahu. 2005. Studies on variability, heritability and genetic advance in scented rice germplasm accessions. Journal of Interacademicia. 9(4): 487-489.

Sharma, R.K. and S. C. Mani. 2001. Combining ability studies for grain yield and other associated characters in basmati rice (Oryza sativa L.). Crop Improvement. 28(2): 236-243.

Shehata, S. M. 2004. Lines $x$ testers analysis of combining ability under salinity and drought conditions in rice. (Oryza sativa). Egyptian J. of Agric. Res. 82(1): 119-138.

Soroush, H. R. and A. Moumeni. 2006. Genetic dissection of some important agronomic characters in rice using line $x$ tester analysis. Journal of Science and Technology of Agriculture and Natural Resources. 10(1): 177-187.

Steel, R.D and J.H. Torrie. 1980. Principal and Procedures of Statistics. McGraw Hill Book Co., New York.

Verma, O. P. and H. K. Srivastava. 2004. Genetic component and combining ability analyses in relation to heterosis for yield and associated traits using three diverse rice-growing ecosystems. Field Crops Research. 88(2/3): 91-102.

Viswanathan Satheesh and K. Thiyagarajan. 2008. Combining ability studies for yield and yield components in rice (Oryza sativa L.). International Journal of Plant Sciences (Muzaffarnagar). 3: 1, 61-68.

Wricke, H. and W. E. Weber. 1986. Quantitative genetics and selection in plant breeding. Berlin: Walter de Gruyter and Co. 
Hassan, H. M. et al.

تقدير القدرة على التألف وقوة الهجين باستخدام تصميم السـلالة X الكثـاف تحت ظروف الاجهاد المائى فى الأرز

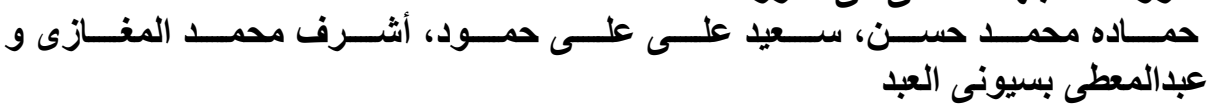
قسم بحوث الارز - معهد بحوث المحاصيل الحقلية ـ مركز البحوث الزراعية ـ الجيزة ـ مصـر

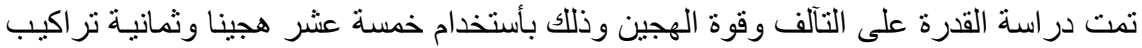

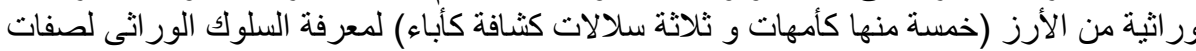

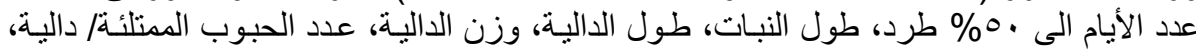

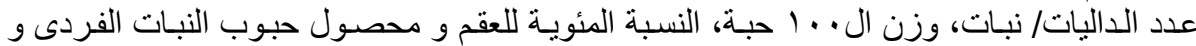

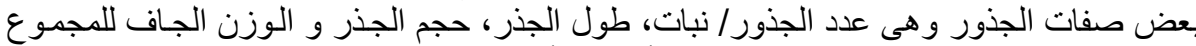

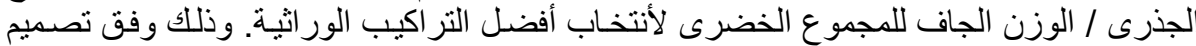

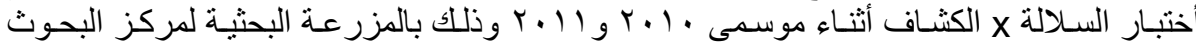

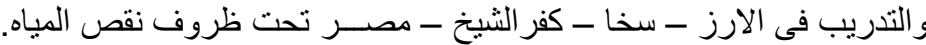

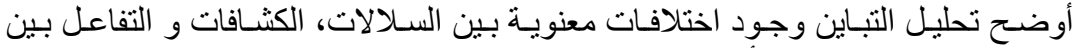

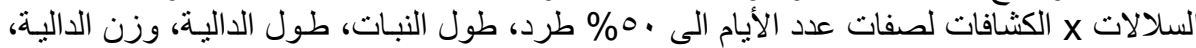

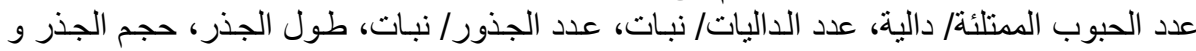

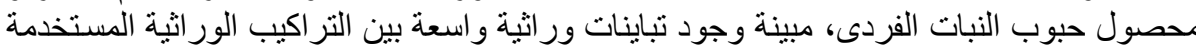

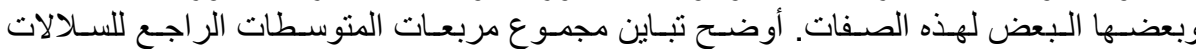

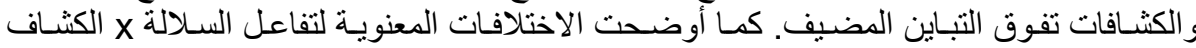

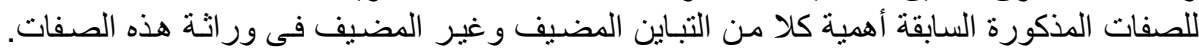

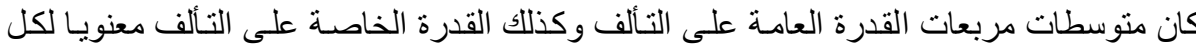

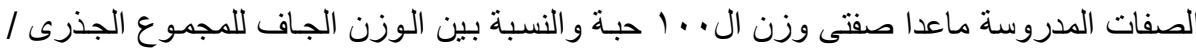

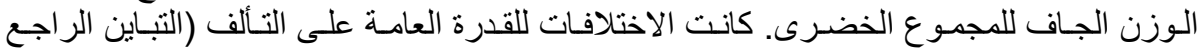

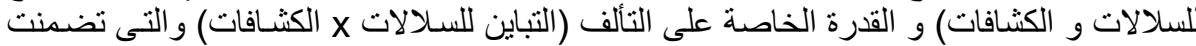

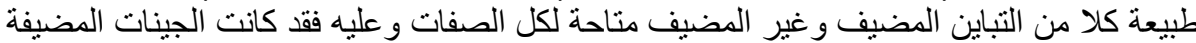

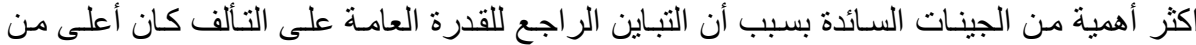

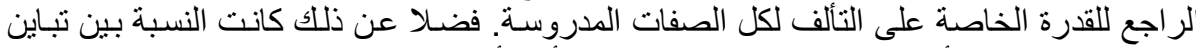

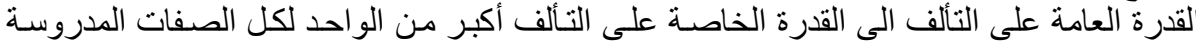

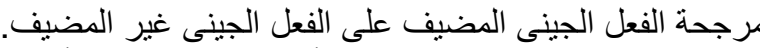

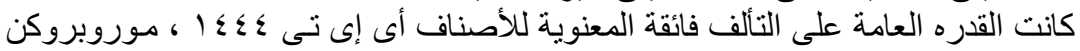

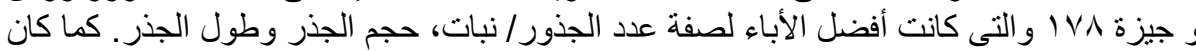

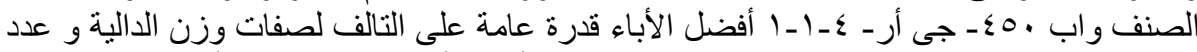

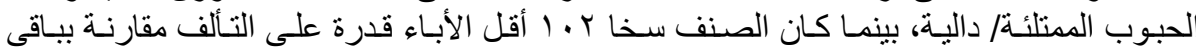

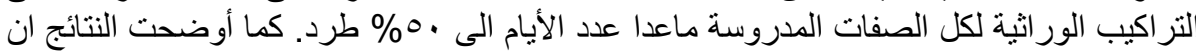

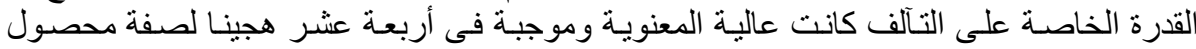

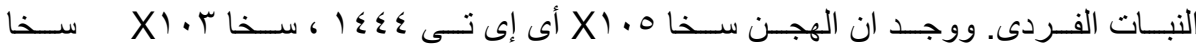

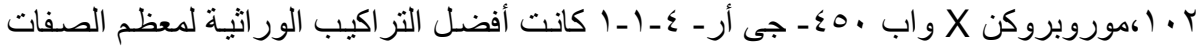

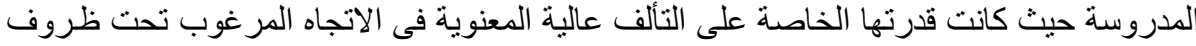

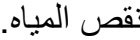

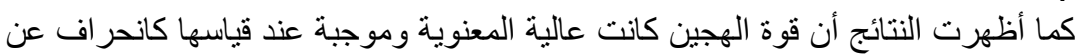

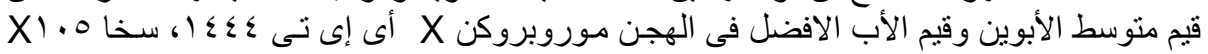




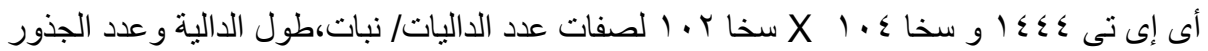

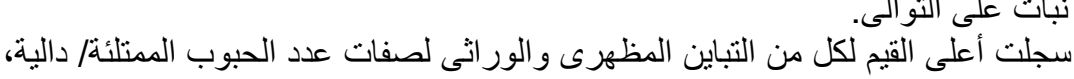

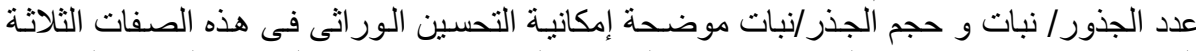

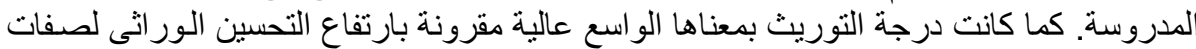

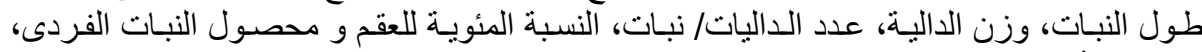

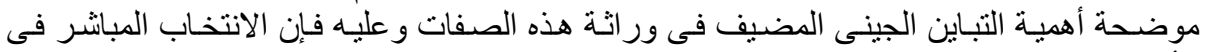
الأجيال المبكرة يكون اكثر فاعلية لتحسين هذه الصفات تحت ظروف لفين نفص المياه.

كلية الزراعة - جامعة المنصورة

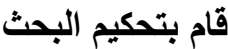
مركز البحوث الزراعية أ.د / أدمد نادر اليد السيد عطيه أ.د / أد / عبد السلام عبيد دراز السيد عطيه 
Table (4): Estimates of specific combining ability effects for the studied traits under water stress conditions during 2011 growing season.

\begin{tabular}{|c|c|c|c|c|c|c|c|c|c|c|c|c|c|}
\hline Genotypes & \begin{tabular}{|c} 
Duration \\
(days)
\end{tabular} & $\begin{array}{c}\text { Plant } \\
\text { Height } \\
\text { (cm) }\end{array}$ & $\begin{array}{c}\text { Panicle } \\
\text { Length } \\
\text { (cm) }\end{array}$ & $\begin{array}{c}\text { Panicle } \\
\text { weight } \\
\text { (g) }\end{array}$ & \begin{tabular}{|c|}
$\begin{array}{c}\text { No. of } \\
\text { filled } \\
\text { grains/ } \\
\text { panicle }\end{array}$ \\
\end{tabular} & $\begin{array}{c}\text { Sterility } \\
\text { (\%) }\end{array}$ & $\begin{array}{c}\text { No. of } \\
\text { Panicles/ } \\
\text { plant }\end{array}$ & \begin{tabular}{|c|}
$100-$ \\
grain \\
weight \\
(g)
\end{tabular} & $\mid \begin{array}{c}\text { Root } \\
\text { numbers }\end{array}$ & $\begin{array}{c}\text { Root } \\
\text { Volume } \\
\text { (cm) }\end{array}$ & $\begin{array}{c}\text { Root } \\
\text { Length } \\
\text { (cm) }\end{array}$ & $\begin{array}{c}\text { Root } \\
\text { /Shoot } \\
\text { Ratio }\end{array}$ & $\begin{array}{c}\text { Grain } \\
\text { yield/ } \\
\text { Plant (g) }\end{array}$ \\
\hline Giza 178 x IET 1444 & 1.08 & $-4.31^{*}$ & -1.74 & 0.10 & $6.07^{*}$ & $1.67^{*}$ & -1.35 & -0.11 & -10.87 & $-13.82^{* *}$ & $2.47^{*}$ & $0.21^{* *}$ & $-1.98^{\star}$ \\
\hline Giza 178 x Sakha 102 & $-3.17^{* *}$ & $7.16^{\star \star}$ & 0.66 & $-0.30^{* *}$ & -0.47 & 1.36 & 1.30 & 0.09 & -7.07 & 7.64 & 0.13 & -0.04 & -1.18 \\
\hline Giza 178 x WAB 450 & 2.09 & -2.84 & 1.06 & $0.20^{\star *}$ & $-5.60^{*}$ & -3.02 & 0.04 & 0.02 & $17.93^{* *}$ & 6.18 & $-2.60^{*}$ & $-0.16^{\star *}$ & $3.17^{* *}$ \\
\hline Sakha 103 x IET 1444 & -0.80 & 0.47 & -0.14 & $-0.30^{* *}$ & $-8.49^{\star \star}$ & 0.66 & -1.12 & -0.06 & $-23.87^{* *}$ & $-21.93^{* *}$ & $-3.53^{* *}$ & 0.01 & 0.16 \\
\hline Sakha 103 x Sakha 102 & -1.07 & -2.73 & 0.47 & $0.42^{\star *}$ & $16.64^{* *}$ & $-2.38^{\star *}$ & -0.79 & 0.01 & $30.27^{\star *}$ & $23.20^{\star *}$ & 1.13 & $-0.11^{\star *}$ & 1.19 \\
\hline Sakha 103 x WAB 450 & 1.87 & 2.27 & -0.33 & -0.12 & $-8.16^{* *}$ & $1.72^{*}$ & $1.91^{*}$ & 0.04 & -6.40 & -1.27 & $2.40^{*}$ & $0.11^{\star *}$ & -1.35 \\
\hline Sakha 104 x IET 1444 & 1.53 & -2.42 & -0.54 & -0.12 & $-6.71^{*}$ & $1.61^{*}$ & -1.02 & -0.01 & $26.47^{* *}$ & $20.51^{\star *}$ & $-2.42^{*}$ & 0.03 & 0.38 \\
\hline Sakha 104 x Sakha 102 & $2.60^{*}$ & $-4.29^{*}$ & -0.85 & 0.07 & $-14.58^{\star *}$ & -1.12 & -0.36 & 0.02 & $22.60^{\star *}$ & $26.98^{\star *}$ & 0.91 & $-0.10^{*}$ & $-2.38^{\star *}$ \\
\hline Sakha 104 x WAB 450 & $-4.13^{\star *}$ & $6.71^{\star *}$ & 1.40 & 0.05 & $21.29^{* *}$ & -0.48 & 1.38 & -0.01 & $-49.07^{\star \star}$ & $-47.49^{* *}$ & 1.51 & 0.06 & $2.00^{*}$ \\
\hline Sakha 105 x IET 1444 & $-3.58^{* *}$ & 3.02 & $2.11^{*}$ & $0.22^{* *}$ & 1.84 & $-3.77^{* *}$ & $2.09^{*}$ & 0.10 & -0.64 & 1.29 & $2.80^{*}$ & $-0.26^{* *}$ & $3.11^{* *}$ \\
\hline Sakha 105 x Sakha 102 & $3.49^{* \star}$ & -3.51 & -0.10 & 0.14 & 0.98 & 0.98 & 0.75 & $-0.18^{\star}$ & 8.49 & 2.09 & 0.80 & $0.23^{* *}$ & $-2.82^{\star *}$ \\
\hline Sakha 105 x WAB 450 & 0.09 & 0.49 & $-2.00^{*}$ & $-0.37^{\star *}$ & -2.82 & $2.79^{\star *}$ & $-2.84^{* *}$ & 0.08 & -7.84 & -3.38 & $-3.60^{\star \star}$ & 0.02 & -0.29 \\
\hline Morobrekan x IET 1444 & 1.76 & 3.24 & 0.32 & 0.10 & $7.29^{*}$ & -0.15 & 1.40 & 0.08 & 8.91 & $13.96^{* *}$ & 0.69 & 0.01 & -1.68 \\
\hline Morobrekan x Sakha 102 & -1.84 & 3.38 & -0.19 & $-0.34^{\star *}$ & -2.58 & 1.17 & -0.90 & 0.05 & $-54.29^{* *}$ & $-59.91^{* *}$ & $-2.98^{\star \star}$ & 0.02 & $5.21^{* *}$ \\
\hline Morobrekan x WAB 450 & 0.09 & $-6.62^{* *}$ & -0.13 & $0.24^{\star \star}$ & -4.71 & -1.01 & -1.35 & -0.11 & -10.87 & $-13.82^{* *}$ & $2.47^{*}$ & $0.21^{* *}$ & $-1.98^{*}$ \\
\hline S.E (Sij) & 1.31 & 1.90 & 1.04 & 0.09 & 3.28 & 0.82 & 1.30 & 0.09 & -7.07 & 7.64 & 0.13 & -0.04 & $\begin{array}{l}-1.18 \\
\end{array}$ \\
\hline S.E (Sij-Skl) & 1.86 & 2.69 & 1.47 & 0.13 & 4.64 & 1.17 & 0.04 & 0.02 & $17.93^{\star \star}$ & 6.18 & $-2.60^{\star}$ & $-0.16^{\star \star}$ & $3.17^{\star *}$ \\
\hline L.S.D 0.05 & 2.37 & 3.43 & 1.88 & 0.16 & 5.23 & 1.48 & -1.12 & -0.06 & $-23.87^{\star \star}$ & $-21.93^{\star \star}$ & $-3.53^{\star \star}$ & 0.01 & 0.16 \\
\hline 0.01 & 3.03 & 4.40 & 2.41 & 0.20 & 7.60 & 1.90 & -0.79 & 0.01 & $30.27^{\star \star}$ & $23.20^{\star \star}$ & 1.13 & $-0.11^{\star \star}$ & 1.19 \\
\hline
\end{tabular}

${ }^{*}$ and ${ }^{\star *}$ significant at 0.05 and 0.01 probability levels, respectively. 